\title{
Temperature Influence on Pseudothecia Development Stages of Venturia inaequalis in the Western Cape of South Africa
}

\author{
S. G. von Diest, ${ }^{1}$ J. C. Meitz-Hopkins, ${ }^{1, \dagger}$ A. A. Rabie, ${ }^{1}$ W. E. MacHardy, ${ }^{2}$ and C. L. Lennox ${ }^{3}$ \\ ${ }^{1}$ Fruit and Postharvest Pathology Research Programme, Department of Plant Pathology, Stellenbosch University, Matieland \\ 7602, South Africa \\ ${ }^{2}$ Department of Plant Biology, University of New Hampshire, Durham, NH, U.S.A. \\ ${ }^{3}$ Fruit and Postharvest Pathology Research Programme, Department of Plant Pathology, Stellenbosch University, Matieland \\ 7602, South Africa
}

\begin{abstract}
Pseudothecia development stages of Venturia inaequalis (apple scab) were investigated in two climatically different regions in the Western Cape of South Africa. The aim was to determine the pseudothecial density (PD; pseudothecia per fertile lesion $[\mathrm{p} / \mathrm{f}])$ and ascal density (AD; asci per pseudothecium $[\mathrm{a} / \mathrm{p}]$ ) that contributes to defining the potential ascospore dose in a common prediction model of the apple scab infection risk. The PD and AD were compared between Elgin (EL), now considered a warm winter apple-growing region because of climate warming, and Koue Bokkeveld (KB), a cold winter region. In 2012 and 2013, scabbed apple leaves were collected during leaf-drop in

KB and overwintered in EL (mean, $17.11 \mathrm{p} / \mathrm{f} ; P<0.001$ ). PD of scabbed leaves collected and overwintered in EL (mean, $15.27 \mathrm{p} / \mathrm{f}$ ) or collected in EL and overwintered in KB (mean, 16.07 p/f) did not differ significantly. Ascal density did not differ significantly in any treatment or season. We concluded that the significantly higher PD of scabbed leaves collected from the cooler region of $\mathrm{KB}$ and overwintered in $\mathrm{KB}$ compared with scabbed leaves collected in EL or KB and overwintered in EL could be caused by adaptations of $V$. inaequalis populations to the respective climates. This implied long-term effects of climate warming on apple scab epidemiology and management.
\end{abstract} $\mathrm{KB}$ and EL and overwintered either in their region of origin or in the other region. PD was significantly higher in scabbed leaves collected and overwintered in KB (mean, $24.11 \mathrm{p} / \mathrm{f}$ ) than in leaves collected in

Keywords: climate/weather effects, disease development and spread, fruit, fungi, tree fruits

The South African apple industry is primarily export-driven, and apple scab (Venturia inaequalis [Cooke] Winter) is the most economically important disease of apples (Malus $\times$ domestica Borkh.) in the country. Scab management in South Africa is largely reliant on preventative fungicide sprays, which are applied depending on local weather patterns. Farmers use the iLeaf tool (http://ileafweather. com/LogIn.aspx), which predicts the so-called Fusi index (MeitzHopkins et al. 2014). Changing weather patterns over the past 40 years were characterized by a warming trend during all seasons for most regions in the Western Cape of South Africa (i.e., $+0.4^{\circ} \mathrm{C}$ per decade during June to August), and an increase in air temperatures of $1^{\circ} \mathrm{C}$ to $2^{\circ} \mathrm{C}$ is predicted over the next 30 years (Hao et al. 2018; Midgley and Lötze 2011). In Koue Bokkeveld (KB), at an elevation of $\approx 900 \mathrm{~m}$, which is regarded as a cold winter apple-growing region in the Western Cape, temperatures are within the optimum chilling range of apple, as evidenced by the adequate chilling units and a normal growth pattern of apple trees in that region (Midgley and Lötze 2011). In Elgin (EL), which is regarded as a warm winter applegrowing region at an elevation of $305 \mathrm{~m}$ (Midgley and Lötze 2011), apple trees have responded to climatic warming with delayed or incomplete leaf-drop, not fully entering dormancy, and showing uneven bud-break and bloom (Cook 2010; Gladieux et al. 2008).

${ }^{\dagger}$ Corresponding author: J. C. Meitz-Hopkins; juliam@sun.ac.za

Funding: HORTGRO and the National Research Foundation (THRIP) provided funding for this project.

*The $\boldsymbol{e}$-Xtra logo stands for "electronic extra" and indicates that one supplementary figure and one supplementary table are published online.

The author(s) declare no conflict of interest.

Accepted for publication 26 July 2019.

(c) 2020 The American Phytopathological Society
Changes in apple tree phenology caused by climate change have also been reported in Lithuania and Germany (Kunz and Blanke 2011; Romanovskaja and Bakšiene 2009).

Effective management of apple scab relies on accurate information regarding the epidemiology of the pathogen in each region (Gadoury and MacHardy 1982a). Venturia inaequalis typically occurs in an asexual (conidial) form during summer and a sexual (ascosporic) form during winter (MacHardy et al. 2001). Considering the increasing evidence of climate change in the Western Cape and its influence on apple tree phenology, the potential effects on certain aspects of the lifecycle of $V$. inaequalis require investigation.

To determine the risk of primary scab infection during spring for a specific apple orchard, the potential ascospore dose (PAD) per square meter of the orchard floor should be calculated to aid producers when making informed decisions about which orchards require more immediate preventative scab management during spring (Gadoury and MacHardy 1986; Sutton et al. 2000). To estimate the PAD, it is necessary to first establish the following parameters for the resident $V$. inaequalis population: pseudothecial density (PD; number of mature pseudothecia per fertile lesion [p/f]) and ascal density (AD; the number of asci per pseudothecium $[\mathrm{a} / \mathrm{p}]$ ); lesion density (LD); and leaf litter density (LLD). PAD $>600$ indicates that an orchard is at risk for apple scab infection, and it can be calculated as follows:

$$
\mathrm{PAD}=\mathrm{LD} \times \mathrm{AD} \times \mathrm{LLD} \times \mathrm{n}
$$

With the number of ascospores (n) being a constant of 8 for $V$. inaequalis. LD and LLD are orchard-specific and season-specific factors determined near harvest time. Constants for PD (21.6 p/f) and AD $(122 \mathrm{a} / \mathrm{p})$ have been determined for $V$. inaequalis populations in New Hampshire in the northeastern United States (Gadoury and MacHardy 1986), but they may not apply to South Africa. To date, determination of $\mathrm{PD}$ and $\mathrm{AD}$ have not been reported for South Africa; therefore, PAD cannot be accurately measured in South Africa until constants for these factors have been determined.

$\mathrm{PD}$ and $\mathrm{AD}$ are dependent on environmental conditions after leafdrop and during winter (Gadoury and MacHardy 1982a, b; Louw 
1951). Many studies have investigated the effects of temperature on pseudothecia-development, and the effects of temperature, humidity, and light on the production, development, and maturation of ascospores (Brook 1969; James and Sutton 1982a, b; Gadoury and MacHardy 1982b; Gadoury et al. 1998; Gadoury et al. 2004; Szkolnik 1969; Wilson 1928). Most pseudothecia are formed within the first 4 weeks after leaf-drop (Gadoury and MacHardy 1982b); therefore, temperatures and humidity during the first 4 weeks after complete leaf-drop also directly affect PD (James and Sutton 1982a). The number of pseudothecia increased at a rate inversely proportional to temperatures between $4^{\circ} \mathrm{C}$ and $20^{\circ} \mathrm{C}$, but pseudothecial diameter increased most rapidly at $10^{\circ} \mathrm{C}$ and barely developed above $20^{\circ} \mathrm{C}$ under both field and laboratory conditions (Gadoury and MacHardy 1982b; James and Sutton 1982a; Louw 1951).

However, Louw (1951) found that pseudothecia could form at temperatures as low as $1^{\circ} \mathrm{C}$, and that they were most abundant at $13^{\circ} \mathrm{C}$ in the Western Cape of South Africa. Relatively high temperatures $\left(>13^{\circ} \mathrm{C}\right)$ may restrict the initial formation of pseudothecia, which may affect later developmental stages of pseudothecia and ascospores (Louw 1951). Pseudothecial maturation during spring in the Western Cape winter rainfall region was most rapid between $13^{\circ} \mathrm{C}$ and $23^{\circ} \mathrm{C}$ (Louw 1951). Furthermore, differences in temperature ranges and temperature optima for pseudothecial formation between different monoconidial isolates of $V$. inaequalis in the Western Cape were found, with the optimal temperature being higher than the optimum recorded in previous American studies (Louw 1948).

Louw (1948) also considered it likely that $V$. inaequalis may adapt to different climates, and that strains with higher temperature optima could adapt and be dominant in warmer regions, and vice versa. The number of asci per pseudothecium increased at a rate inversely proportional to temperatures between $6^{\circ} \mathrm{C}$ and $20^{\circ} \mathrm{C}$ before the beginning of ascospore maturation; after which, temperature had no significant effect on ascus production (Gadoury et al. 1984). During the final ascospore maturation stage during spring, the optimal temperature has been reported as $20^{\circ} \mathrm{C}$ in the United States (Wilson 1928), in the Western Cape of South Africa (Louw 1951), and in New Hampshire (in the United States) (Gadoury and MacHardy 1982b). However, this optimum was reported to be $16^{\circ} \mathrm{C}$ to $18^{\circ} \mathrm{C}$ in North Carolina (in the United States) (James and Sutton 1982a). Based on the direct effects of temperatures and precipitation on PD and AD, these parameters should be determined for each climatic region when using PAD to accurately determine the risk of disease for an orchard in the following season (Gadoury and MacHardy 1986).

The objective of this study was to determine the differences in overwintering structures of sexual inoculum of $V$. inaequalis and their relationship with weather conditions in the two apple production areas of the Western Cape in South Africa by comparing the EL region, where apple tree phenology is affected by a warming trend, and $\mathrm{KB}$, which is a cooler region.

\section{Materials and Methods}

Trial orchards. Two Braeburn orchards in the Western Cape were selected for this study: one 2.3-ha orchard in EL and one 5.25-ha orchard in the KB region. Both orchards were under high-density cultivation, and leaves were used from the unsprayed, untreated control block (negative control) as described by von Diest et al. (2016). The EL orchard was planted in 1994 on seedling rootstocks, with tree spacing of 4.0 by $1.2 \mathrm{~m}$, whereas the $\mathrm{KB}$ orchard was planted in 1989 on M25 rootstocks, with tree spacing of 4.5 by $1.5 \mathrm{~m}$.

Sample collection. Approximately 1000 senescent, scabbed leaves from trees across each orchard ( $>100$ per treatment; region of overwintering and origin) were detached during leaf-drop in May and June in 2012 and 2013. Detached leaves were kept in brown paper bags in darkness at room temperature and were transferred to the overwintering sites within 2 days to ensure that the temperature influence on PD occurred almost entirely during leaf storage at the overwintering sites. Leaves originating from $\mathrm{KB}$ were collected by mid-May 2012 (week 21; 70\% leaf-drop) and in May 2013 (week 22; $90 \%$ leaf-drop). Leaf-drop in EL is usually delayed because of warmer winters; therefore, leaves originating from EL were collected twice, once during week 20 (70\% leaf-drop) and once during week 25 (90\% leaf-drop), in 2012. In 2013, leaves overwintered in both regions were collected at $90 \%$ leaf-drop during week 20 in KB and during week 26 in EL.

Overwintering leaves. Leaves were placed in experimental plots (replicates of three each per treatment) for overwintering on the same day or within the following 2 days after being collected to limit storage time and any potential effect that storage may have on pseudothecial formation and/or development.

A reciprocal transplant design was selected to evaluate the effects of overwintering temperature differences in the $\mathrm{KB}$ and EL regions on pseudothecia and ascal densities (Blanquart et al. 2013). One hundred scabbed leaves with two, three, or four lesions were selected for each treatment to avoid overlapping of fertile lesions. Treatments $\mathrm{KB}-\mathrm{KB}$ and EL-EL comprised leaves from the region of origin that were overwintered in the same region and were used as the negative control treatments. Treatment KB-EL and EL-KB comprised leaves from the region of origin and overwintered in the other region. To prevent displacement of the leaves by wind and removal by earthworms, the leaves were overwintered with the adaxial (top) side facing upward on top of two layers of beige netting (20\% shade) and underneath $1 \mathrm{~m}^{2}$ of dark green hardware netting $(4 \times 4 \mathrm{~cm})$ secured to the ground.

Table 1. Mean weekly temperatures and precipitation and mean pseudothecial densities per treatment of leaves from Koue Bokkeveld (KB) or Elgin (EL) (region of origin) and overwintered in KB or EL (region of overwintering) in 2012 and 2013

\begin{tabular}{|c|c|c|c|c|c|c|}
\hline \multirow[b]{2}{*}{ Region of origin } & \multirow[b]{2}{*}{ Region of overwintering (week) } & \multicolumn{5}{|c|}{$2012^{u}$} \\
\hline & & PDv $^{\mathbf{v}} 2012$ & Temp., ${ }^{\circ} \mathrm{C}^{\mathrm{w}}$ & Average $\mathbf{C U}^{\mathrm{x}}$ & Average rain, $\mathbf{m m} /$ day $^{y}$ & No. rain events \\
\hline KB & KB [21-24] & $24.7 \mathrm{a}$ & $9.20( \pm 1.38) b$ & $12.91( \pm 2.09)$ & $9.4( \pm 0.9)$ & 11 \\
\hline KB & EL [21-24] & $15.2 \mathrm{~b}$ & $10.73( \pm 0.49)$ a & $9.55( \pm 2.02)$ & $4.5( \pm 6.7)$ & 19 \\
\hline EL & EL [20-23] & & $11.42( \pm 0.94) \mathrm{a}$ & $7.59( \pm 2.28)$ & $5.3( \pm 6.2)$ & 16 \\
\hline EL & EL [25-28] & & $10.27( \pm 1.07) \mathrm{a}$ & $9.18( \pm 2.74)$ & $4.7( \pm 2.5)$ & 23 \\
\hline EL & EL [avg. $20-23,25-28]^{\mathrm{z}}$ & $12.7 \mathrm{c}$ & & & & \\
\hline EL & $\mathrm{KB}[20-23]$ & & $11.15( \pm 2.64) \mathrm{a}$ & $8.32( \pm 7.25)$ & $9.7( \pm 1.1)$ & 13 \\
\hline EL & KB [25-28] & & $7.93( \pm 0.96) \mathrm{b}$ & $18.50( \pm 2.67)$ & $7.1( \pm 1.3)$ & 16 \\
\hline
\end{tabular}

EL $\quad$ KB [avg. 20-23, 25-28 $]^{\mathrm{z}} \quad 13.8 \mathrm{c}$

(Continued on next page)

\footnotetext{
"Means with the same letters do not differ significantly $(P<0.05)$.

v PD (pseudothecial density) $=$ number of mature pseudothecia per visible lesion

${ }^{\mathrm{w}}$ Temp. $=$ mean weekly dry bulb temperatures $\left({ }^{\circ} \mathrm{C}\right)$ during the first 4 weeks when the leaves were overwintered in the respective treatments, when most pseudothecia were expected to form $( \pm \mathrm{SD})$

x Richardson cold units (CU) recorded by Ileaf.co.za weather stations ( $\pm \mathrm{SD})$.

y Average weekly recorded rainfall $(\mathrm{mm})$ per day of rain events $(>0.2 \mathrm{~mm})$ during the first 4 weeks of overwintering $( \pm \mathrm{SD})$.

${ }^{\mathrm{z}}$ Leaf discs were collected in a staggered manner (weeks 19 or 20 and 24) and pooled; therefore, overwintering weather data from weeks 20 to 23 or 21 to 24 and 25 to 28 , which were most relevant, are shown.
} 
Determining pseudothecial densities. Autumn foliar scab was 30 and $10 \%$ in 2012 and 49 and $12 \%$ in 2013 in the EL and KB orchards, respectively. In mid-August 2012 and 2013, 30 scabbed leaves from each orchard were cleared using a modified protocol (Shobe and Lersten 1967) and placed in $25 \mathrm{ml}$ of aqueous $2 \mathrm{M}$ $\mathrm{NaOH}$ (8 g/100 ml; Merck, South Africa) solution in 9-cm plastic petri dishes and allowed to discolor in the $\mathrm{NaOH}$ solution for 3 days. Then, the solution was discarded, and another $25 \mathrm{ml}$ of $\mathrm{NaOH}$ was added to each petri dish containing the leaves to allow further discoloration for 1 additional day. Petri dishes with leaves were placed on a Bellydancer Shaker (Stoval, Life Science Inc., Greensboro, NC) for $2 \mathrm{~h}$ at a low speed to allow further discoloration. The $\mathrm{NaOH}$ was then discarded and leaves were rinsed three times with distilled water; then, $4 \mathrm{ml}$ of aqueous chloral hydrate $(200 \mathrm{~g} / 100 \mathrm{ml}$; SigmaAldrich) was added to each petri dish. After 1 day, the leaves were rinsed with distilled water and dehydrated with $95 \%$ ethanol.

Leaves were covered with a glass slide in the petri dishes and viewed under a Nikon SMZ 1500 stereo microscope. Digital photographs were taken of 100 fertile lesions (Nikon Digital Camera DXM1200C and NIS-Elements F 3.0 software), and the pseudothecia associated with each fertile lesion were counted. To be included in the counts, pseudothecia had to have a subcutaneous hyphal connection, a suitable size, a visible ostiole, and brown color. Those with small fruiting structures, no brown color, and no visible ostiole (surrounded by hair-like setae) and those covered in hyphae and not distinguishable were not counted.

Determining ascal densities. During week 31 of both years (2012, 2013) leaves in each overwintering treatment plot were moved to an outdoor shelter with two open sides near the treatment plots to keep the leaves dry to prevent ascospore discharge while maintaining them at the same environmental temperature as nonprotected leaves. Leaves were wetted artificially every day that it rained, but only in darkness before sunrise or after sunset, when few or no ascospores are discharged (Gadoury et al. 1998). In late August 2012 and early September 2013, protected overwintered leaves from each treatment were collected, and randomly selected pseudothecia from each treatment were picked off with a scalpel and transferred to a drop of lactic acid on a microscope slide. Squash mounts were prepared using the methods described by Gadoury and MacHardy (1982a). A coverslip was placed over the pseudothecium, and pressure was applied to break the pseudothecial wall and allow the asci to spread evenly on the slide. Asci inside each pseudothecium were counted by viewing the squash mounts at $40 \times$ magnification on a Nikon Eclipse E600 light microscope.

Determining lesion density. The LD refers to the foliar scab severity and is orchard-specific. Therefore, LD has to be determined in each orchard at leaf-drop (Gadoury and MacHardy 1986; Sutton et al. 2000). Therefore, the percentage of leaf area visibly infected by scab (severity) was estimated by rating all leaves on 60 extension shoots per orchard as described previously (Kremer and Unterstenhöfer 1967).

Determining leaf litter densities. The percentage of ground covered by leaf litter (LLD) was estimated in June 2012 and 2013 (100\% leaf-drop) using the point-intercept method described by Gadoury and MacHardy (1986).

Temperature and precipitation data for pseudothecial and ascal densities. Hourly temperature $\left({ }^{\circ} \mathrm{C}\right)$ and precipitation $(\mathrm{mm})$ in 2012 and 2013 were monitored at permanent weather stations ("Elgin Orchards" and "Nooitgedacht") a maximum $1 \mathrm{~km}$ from the respective experimental sites. Weather data were obtained from iLeaf Integrated Weather Data Interpretation Software (http:// www.ileaf.co.za). Richardson cold units were chosen to estimate the effects of hourly temperatures according to the scale provided by Anderson et al. (1986). Temperatures between $1.5^{\circ} \mathrm{C}$ and $12.4^{\circ} \mathrm{C}$ would positively contribute to cold units, whereas temperatures above $12.5^{\circ} \mathrm{C}$ would not be suitable for the pathogen to form mating structures. Richardson cold unit estimation is included in the horticulture service provided to the pome fruit producers by Hortec (www.ileaf.co.za), whereas the hours of temperatures below $0^{\circ} \mathrm{C}$ had to be assessed through additional calculations from the acquired weather data using Excel. Pseudothecia have been reported to form during the first 4 weeks after overwintering began (Gadoury and MacHardy 1982b); therefore, temperatures for the first 4 weeks after the leaf sets were transferred to the overwintering site were averaged for each treatment (Tables 1 and 2). The first ascospores usually mature and are ready to be discharged in the Western Cape beginning in mid-August (Louw 1951); therefore, temperatures from the fifth week after overwintering until week 33 (mid-August) in the respective regions were selected to compute the mean temperature for the weeks when asci are expected to develop. The overwintering periods varied between regions because leaf-drop occurred at different time points for individual treatments. The total amount of accumulated rainfall was calculated, as was the number of rain events (if $>0.2 \mathrm{~mm}$ precipitation/hour; events were combined if continuous hours of leaf wetness were recorded).

Statistical analysis. All statistical analyses were performed using the STATISTICA 13 data analysis software system (StatSoft, Inc. 2012, https://docs.tibco.com) at the Centre for Statistical Analysis at Stellenbosch University. Significant differences were evaluated based on a $5 \%$ significance level $(P<0.05)$. A two-way analysis of variance (ANOVA) was used to compare pseudothecial and ascal densities of the different leaf sets. A least significant difference (LSD) test was used for post hoc testing to compare differences between means. Descriptive statistics were used to show differences in mean temperature and precipitation of the $\mathrm{KB}$ and EL regions from 1 May to 31 August in 2012 and 2013, as well as during pseudothecial and ascal formation periods.

Table 1. (Continued from preceding page)

\begin{tabular}{|c|c|c|c|c|c|c|}
\hline \multirow[b]{2}{*}{ Region of overwintering (week) } & \multicolumn{5}{|c|}{$2013^{u}$} & \multirow{2}{*}{$\frac{\text { Mean }^{\mathrm{u}}}{\text { PD 2012, } 2013}$} \\
\hline & PD $^{v} 2013$ & Temp., ${ }^{\circ} \mathrm{C}^{\mathrm{w}}$ & Average $\mathbf{C U}^{\mathbf{x}}$ & Average rain, mm/day ${ }^{y}$ & No. rain events & \\
\hline KB [22-25] & $24.3 \mathrm{a}$ & $8.4( \pm 1.3) b$ & $13.6( \pm 8.8)$ & $8.4( \pm 8.4)$ & 14 & $24.11 \mathrm{a}$ \\
\hline EL [22-25] & $19.4 \mathrm{~b}$ & $11.2( \pm 1.2) \mathrm{a}$ & $4.6( \pm 4.6)$ & $10.0( \pm 8.7)$ & 16 & $17.11 \mathrm{~b}$ \\
\hline EL [26-29] & $18.5 \mathrm{~b}$ & $11.5( \pm 0.8)$ a & $6.9( \pm 1.1)$ & $3.7( \pm 3.9)$ & 13 & $15.27 \mathrm{~b}$ \\
\hline KB [26-29] & $19.9 \mathrm{~b}$ & $8.8( \pm 1.8) b$ & $14.9( \pm 5.2)$ & $3.5( \pm 3.5)$ & 11 & $16.07 \mathrm{~b}$ \\
\hline
\end{tabular}




\section{Results}

Pseudothecial densities. The leaf-clearing method was highly effective for clearing leaf tissue while leaving fungal tissue naturally colored. The alternative leaf-clearing method that used sodium hypochlorite instead of chloral hydrate also bleached fungal tissue, which made it impossible to distinguish between plant and fungal material. Combined data of two seasons showed that PD was significantly higher in scabbed leaves collected and overwintered in KB (24.1 p/f) than in leaves collected in KB and overwintered in EL (17.1 p/f) (Table 1). ANOVA of PD in 2012 indicated that the PD for leaves collected in $\mathrm{KB}$ and overwintered in $\mathrm{KB}(24.7 \mathrm{p} / \mathrm{f} \pm 1.2 \mathrm{SD})$ was significantly higher $(P<0.05)$ than that for KB leaves that overwintered in EL (15.2 p/f \pm 1.2$)$. The PD for leaves collected in EL and overwintered in EL $(12.7 \mathrm{p} / \mathrm{f} \pm 1.3)$ did not differ significantly from EL leaves overwintered in $\mathrm{KB}(13.8 \mathrm{p} / \mathrm{f} \pm 1.3)(P=0.44)$, but the PD of these two treatments was significantly lower than that for leaves collected in $\mathrm{KB}$, regardless of where the leaves overwintered $(P<0.001)$ (Table 1$)$. In 2013, the PD for leaves collected in KB and overwintered in KB (24.3 $\mathrm{p} / \mathrm{f} \pm 1.3$ ) was significantly higher than that for leaves collected in EL and overwintered in EL $(18.5 \mathrm{p} / \mathrm{f} \pm 1.2)$ and for KB leaves that were overwintered in EL $(19.4 \mathrm{p} / \mathrm{f} \pm 1.3)(P<0.001)$. The PD for leaves collected in EL and overwintered in EL did not differ significantly from EL leaves that overwintered in $\mathrm{KB}(19.9 \mathrm{p} / \mathrm{f} \pm 1.3)(P=0.81)$, and the PD of these treatments did not differ from leaves collected in $\mathrm{KB}$ and overwintered in EL $(P=0.48 \mathrm{p} / \mathrm{f}$ and $P=0.64$, respectively $)$ (Table 1). A combined analysis of both seasons $(2012,2013)$ indicated a clear difference in the lower PD of leaves originating from $\mathrm{EL}(P=$ $0.0004)$, even when overwintered in $\mathrm{KB}$, although differences were more pronounced during the first season (Supplementary Fig. 1).

Ascal density. The mean AD in 2012 and 2013 for leaf sets that remained in the region where they originated were not significantly different $(P>0.05)$ (Table 2). Therefore, the 149 AD averaged for all treatments in 2012 and 2013 represented a preliminary AD constant for the EL and $\mathrm{KB}$ regions.

Lesion density. An average of $13.7 \%( \pm 9.5 \%)$ of the leaf area was covered by lesions in Fall 2011 before the beginning of the trials in the EL orchard, whereas approximately $30 \%$ severity was recorded for the KB orchard. In March 2012, apple scab severity on leaves in EL was $17 \%$, whereas that on leaves in $\mathrm{KB}$ was $6.5 \%$.

Leaf litter density. In 2012, the proportions of the orchard floor covered by fallen leaves were $32.8 \%$ in EL and $59.6 \%$ in the KB region at $100 \%$ leaf-drop. During the 2013 season, EL had 55.8\% LLD and KB had 57.6\% LLD.

Potential differences in PAD between regions. To gain preliminary insight regarding the practical consequences resulting from differences in PD between regions. PAD was calculated as:

$$
\operatorname{PAD}_{(\text {Elgin2012) }}=14 \times 12.7 \times 32.8 \times 8=6,951,553
$$

and as:

$$
\operatorname{PAD}_{(\text {KB2012) }}=30 \times 24.3 \times 149 \times 59.6 \times 8=51,790,493
$$

This was a 7.5-times difference in PAD, indicating a higher scab risk for the KB region compared with EL.
Precipitation and temperatures. Precipitation amounts in the two regions were similar in 2012 and in 2013, but the EL region experienced higher rain intensity during weeks 24 and 25 in EL in 2012, and during the first 4 weeks after leaf-drop in 2013 (weeks 21 to 25) (Figure 1, Supplementary Table 1). During both seasons, the rain events tended to last longer in the EL region, i.e., during the first 4 weeks of overwintering (2012: weeks 20 to $23 \mathrm{EL}=98 \mathrm{~h}$, SD \pm 16 ; 2013: weeks 22 to $25 \mathrm{EL}=112 \mathrm{~h}, \mathrm{SD} \pm 18 \mathrm{~h}$ ), than in the KB region (2012: weeks 20 to $23, \mathrm{~KB}=73 \mathrm{~h}, \mathrm{SD} \pm 5 \mathrm{~h}$ ). However, more variation was experienced in KB during season 2013 during weeks 22 to 25 ; the average rain event lasted $76 \mathrm{~h}( \pm 41 \mathrm{~h})$, and long rain periods between 94 and $125 \mathrm{~h}$ occurred during the first 2 weeks (22 to 23 ).

Mean temperatures during the respective pseudothecial and ascal formation stages were lower in KB than in EL during both years (Fig. 2, Tables 1 and 2). In 2012, the average temperatures for the weeks when pseudothecia were expected to form were $10.5^{\circ} \mathrm{C}$ $\left( \pm 0.7^{\circ} \mathrm{C}\right.$ ) in EL (weeks 20 to 24 ) and $9.2^{\circ} \mathrm{C} \pm 1.4^{\circ} \mathrm{C}$ (weeks 20 to 23) and $7.1^{\circ} \mathrm{C} \pm 1.3^{\circ} \mathrm{C}$ (weeks 25 to 28 ) in $\mathrm{KB}$. In 2013, temperatures during leaf overwintering were $11.2^{\circ} \mathrm{C}\left( \pm 1.2^{\circ} \mathrm{C}\right.$ ) in EL (weeks 22 to 25) and $8.4^{\circ} \mathrm{C}\left( \pm 1.3^{\circ} \mathrm{C}\right)$ in $\mathrm{KB}$. Temperatures averaged $11.5^{\circ} \mathrm{C}$ $\left( \pm 0.8^{\circ} \mathrm{C}\right)$ in $\mathrm{EL}$ (weeks 26 to 29$)$ and $8.8^{\circ} \mathrm{C}\left( \pm 1.9^{\circ} \mathrm{C}\right)$ in $\mathrm{KB}$.

In 2012, low temperatures between 0 and $4^{\circ} \mathrm{C}$ in EL occurred 30 times and 40 times in KB (between weeks 24 and 35 in EL and weeks 21 and 35 in $\mathrm{KB}$ ). In the EL region, such "cold spells" lasted between 3 and $11 \mathrm{~h}$; in the KB region, they lasted between 1 and $32 \mathrm{~h}$. Temperatures below $0{ }^{\circ} \mathrm{C}$ were encountered in EL eight times in 2012, lasting between 1 and $6 \mathrm{~h}$; in KB, they occurred five times, lasting between 1 and $5 \mathrm{~h}$. Average weekly cold units potentially affecting pseudothecial density occurred more frequently in the $\mathrm{KB}$ region during weeks 20 to 23 in 2012 and weeks 22 to 24 in 2013 (Fig. 3). During 2 of the 4 weeks of overwintering of leaves when pseudothecia are expected to form, significantly more cold units were recorded in the KB region than in the EL region (weeks 26 to 27 in 2012 and weeks 23 to 24 in 2013, Fig. 4).

The mean temperatures during weeks 29 to 33 (asci development) were $9.7^{\circ} \mathrm{C}( \pm 4.8)$ and $11.1^{\circ} \mathrm{C}\left( \pm 2.0^{\circ} \mathrm{C}\right)$ in $\mathrm{EL}$ in 2012 and 2013 ,

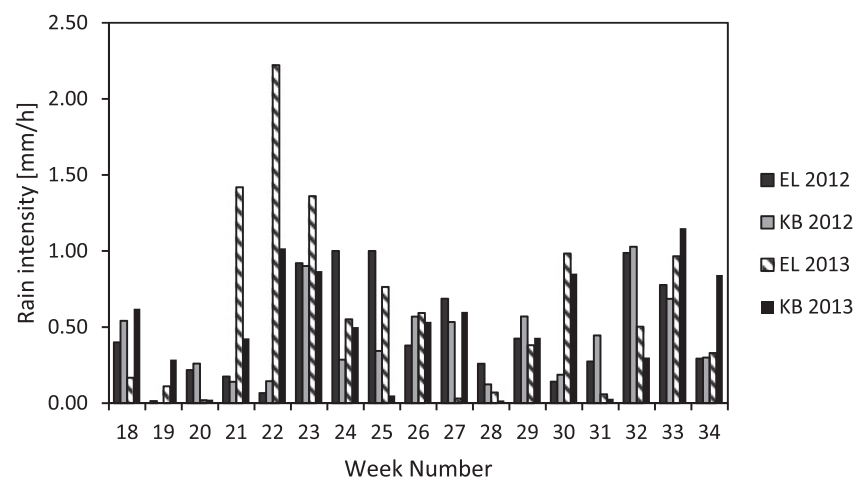

Fig. 1. The average weekly rain intensity ( $\mathrm{mm}$ rain per hour) during rain events in seasons 2012 and 2013 for the Elgin (EL) and Koue Bokkeveld (KB) regions.

Table 2. Mean ascal densities per treatment of leaves from Koue Bokkeveld (KB) or Elgin (EL) (region of origin) and overwintered in KB or EL (region of

\begin{tabular}{|c|c|c|c|c|c|c|c|c|}
\hline \multirow{2}{*}{$\begin{array}{l}\frac{\text { Year }}{\text { Region of }} \\
\text { origin }\end{array}$} & \multirow[b]{2}{*}{$\begin{array}{c}\text { Region of } \\
\text { overwintering (weeks) }\end{array}$} & \multicolumn{3}{|c|}{2012} & \multirow[b]{2}{*}{$\begin{array}{c}\text { Region of } \\
\text { overwintering (weeks) }\end{array}$} & \multicolumn{3}{|c|}{2013} \\
\hline & & $\mathbf{A D}^{\mathbf{y}}$ & $\begin{array}{l}\text { Mean weekly } \\
\text { temp., }{ }^{\circ} \mathbf{C}^{\mathbf{z}}\end{array}$ & $\begin{array}{l}\text { Avg. weekly } \\
\text { rain, mm }\end{array}$ & & AD & $\begin{array}{l}\text { Mean weekly } \\
\text { temp., }{ }^{\circ} \mathrm{C}\end{array}$ & $\begin{array}{l}\text { Avg. weekly } \\
\text { rain, mm }\end{array}$ \\
\hline KB & KB [29-33] & $159.3 \mathrm{ab}$ & $6.9 \mathrm{~b}$ & $34.9 \mathrm{a}$ & KB [29-33] & $144.4 \mathrm{a}$ & $8.9 \mathrm{~b}$ & $28.1 \mathrm{a}$ \\
\hline KB & EL [25-33] & $128.8 \mathrm{a}$ & $10.0 \mathrm{a}$ & $33.6 \mathrm{a}$ & EL [25-33] & $142.1 \mathrm{a}$ & $11.2 \mathrm{a}$ & $32.5 \mathrm{a}$ \\
\hline EL & EL [29-33] & $156.1 \mathrm{ab}$ & $9.8 \mathrm{a}$ & $38.3 \mathrm{a}$ & EL [29-33] & $149.2 \mathrm{a}$ & $11.2 \mathrm{a}$ & $34.4 \mathrm{a}$ \\
\hline EL & KB [23-33] & $162.1 \mathrm{~b}$ & $7.6 \mathrm{~b}$ & $32.7 \mathrm{a}$ & KB [29-33] & $147.6 \mathrm{a}$ & $8.9 \mathrm{~b}$ & $28.1 \mathrm{a}$ \\
\hline
\end{tabular}
overwintering) in 2012 and $2013^{x}$

${ }^{x}$ Means with the same letters do not differ significantly $(P<0.05)$.

${ }^{\mathrm{y}} \mathrm{AD}$ (ascal density) $=$ number of asci per pseudothecia.

${ }^{\mathrm{z}}$ Temp. $=$ mean weekly dry bulb temperatures $\left({ }^{\circ} \mathrm{C}\right)$ from the fifth week after the leaves were overwintered until the middle of August, of the respective treatments, when ascal formation was expected to be the most influenced by temperature. 
respectively. The average temperatures in $\mathrm{EL}$ tended to be higher than the $6.9^{\circ} \mathrm{C}\left( \pm 4.3^{\circ} \mathrm{C}\right)$ and $7.9^{\circ} \mathrm{C}\left( \pm 4.2^{\circ} \mathrm{C}\right)$ measured in $\mathrm{KB}$ in 2012 and 2013, respectively. Differences in Richardson cold units were noticeable during weeks 25 to 27 in 2012, and during weeks 24 to 27 in 2013, in the two regions (Fig. 3). In KB, daily cold units of up to 24 were measured. Temperatures prior to sampling at individual sites were similar in the EL and $\mathrm{KB}$ regions, except during week 19, which was exceptionally warm in 2012 in KB. Furthermore, the parallel analysis of the local population (EL-EL or KB$\mathrm{KB})$ as well as the reciprocal transplant design of the experimental setup ensured an internal control (Blanquart et al. 2013).

\section{Discussion}

The main finding from this study was that the $V$. inaequalis populations from the EL and KB regions are locally adapted to overwinter in the climate of their respective regions because of specialized pseudothecial structures. The practical significance of this result is that in $\mathrm{KB}$, the higher pseudothecia number per leaf lesion indicated a greater impact of sanitation treatments, such as leaf shredding, could be achieved compared with the EL region, where a lower overall number of pseudothecia would develop (von Diest et al. 2016). However, both estimated PAD values were grossly above the threshold value of 600, predicting extreme apple scab infection risk as described by Gadoury and MacHardy (1986) and Sutton et al. (2000). This model would only be relevant to a grower if primary inoculum reduction, such as leaf shredding, was practiced on a large scale for several years.

The differences between the regions were caused by the significantly higher $\mathrm{PD}$ in the $\mathrm{KB}$ region because of the colder winter temperatures routinely experienced there compared with the approximately $2{ }^{\circ} \mathrm{C}$ warmer EL region (weekly averages). Furthermore, the increased intensity of rain events commonly observed during winters in the EL region could have contributed to this change in phenotype.

The PD for leaves collected in KB in 2012 and 2013 and overwintered in KB was significantly higher than that for KB leaves overwintered in EL, most likely caused by the significantly lower temperatures experienced in KB during 2 of the 4 weeks after leafdrop, when pseudothecia develop. These results are consistent with those of previous studies (Gadoury and MacHardy 1982b; Louw 1951) that reported an inverse relationship between temperature during the first 4 weeks after leaf-drop and pseudothecium production. Although temperature differences appear to be the most likely explanation for differences in PD between the two regions, only one orchard was sampled in both regions; therefore, it is not possible to exclude other nonclimate-related differences between the two orchards. To strengthen the evidence, it would be desirable to sample

A

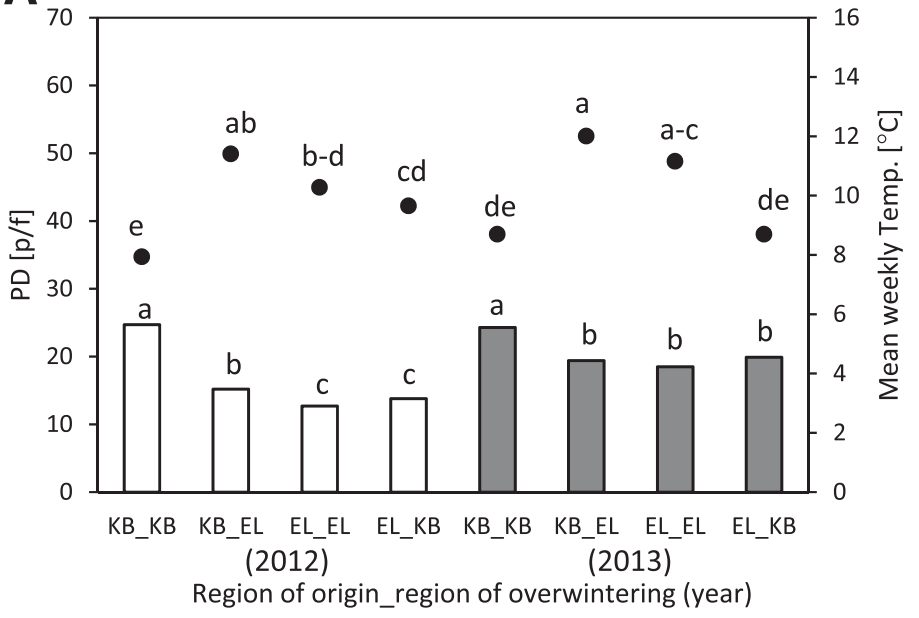

a greater number of orchards per region during a study covering multiple additional seasons.

In 2012 and 2013, the PD in EL-EL and EL-KB did not differ significantly from each other, possibly because of the effects of the warmer and wetter climate in the EL region during pseudothecia development. A similar effect of a milder and wetter climate was found (Holb and Heijne 2002) in Hungary compared with orchards in the Netherlands. The higher PD was attributed to a higher LD in the cooler, drier regions of the Netherlands. The only study of the effect of climate on SA pseudothecia formation was conducted by Louw (1948), who observed consistent, distinct differences in various features (size, color, culture topography, colony margin type, type of submerged growth, amount of aerial mycelia, abundance of conidia) between cultured colonies of different monoconidial $V$. inaequalis isolates in the Western Cape. More importantly, Louw (1948) reported
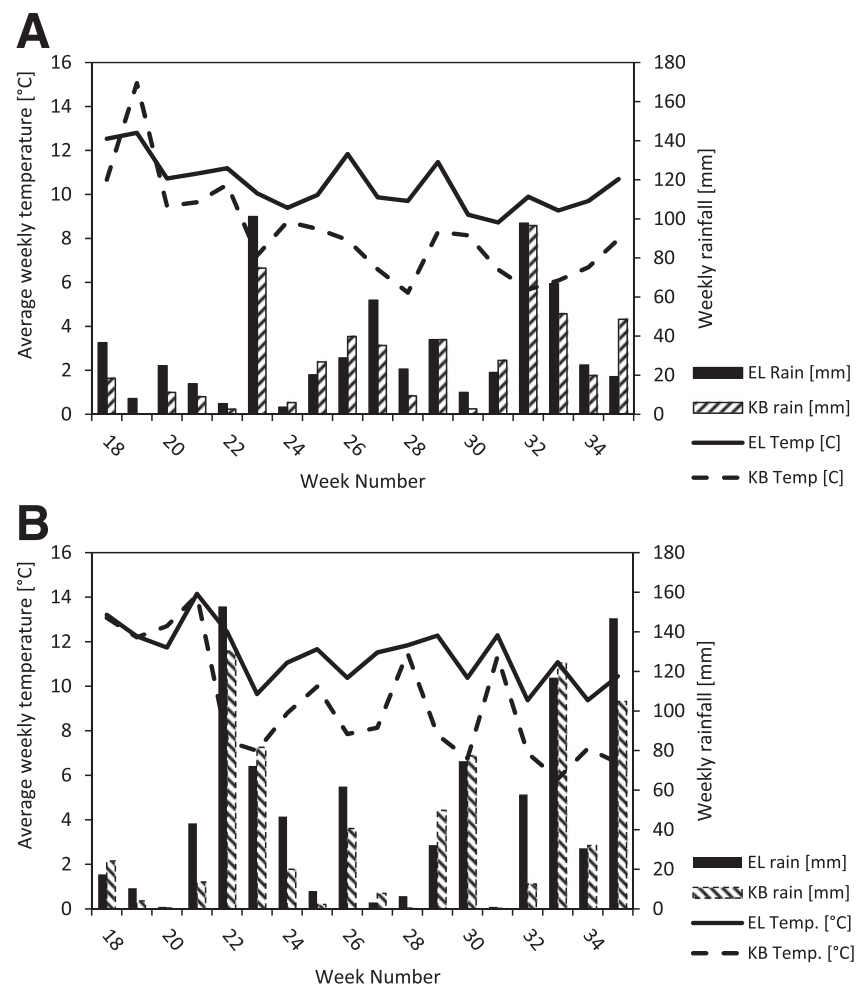

Fig. 3. Average weekly temperatures and rainfall in A, winter 2012 and B, winter 2013 in the Elgin (EL) and Koue Bokkeveld (KB) regions of the Western Cape.

Fig. 2. Relationship between pseudothecial density (PD; pseudothecia per fertile lesion; indicated as white columns for 2012 or gray columns for 2013) and temperature (black circles) during the first 4 weeks of overwintering $(\mathbf{A}, \mathbf{B})$. Letters indicate least significance differences $(P<0.05)$.

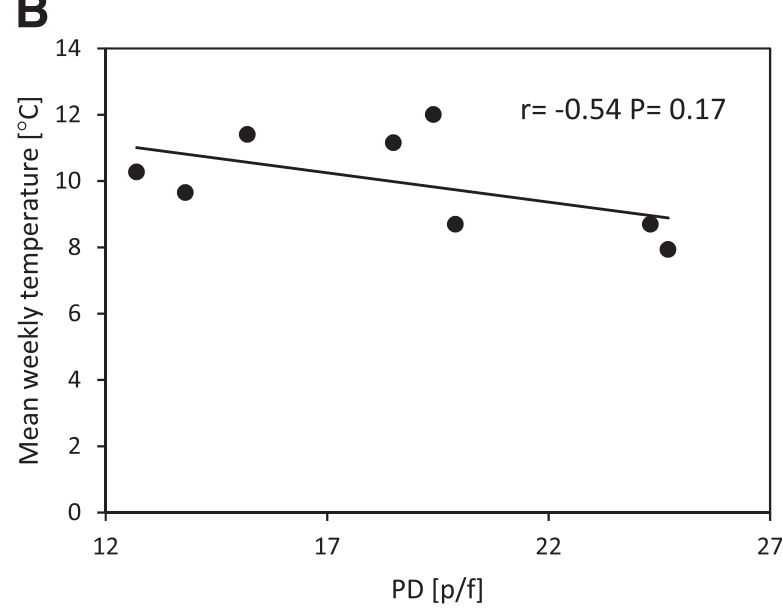


differences in temperature ranges and temperature optima for and abundance of pseudothecial initials between some isolates. One isolate did not produce any pseudothecia on any of the growth media tested, whereas another isolate produced pseudothecia on various media. However, the author stated that "the most divergent types of cultures may be isolated from the same habitat," and "many isolations from individual trees revealed a considerable heterogeneity in their scab populations"; however, identical cultures were obtained from widely separated regions and from apple varieties with very different phenological characters" Louw (1948). Unfortunately, however, the author did not state from where the individual isolates originated. Louw (1951) also found that one isolate in the Western Cape produced pseudothecia when temperatures were between $1{ }^{\circ} \mathrm{C}$ and $23^{\circ} \mathrm{C}$, with an optimal range of 10 to $20^{\circ} \mathrm{C}$, but that another isolate only produced pseudothecia at temperatures between $1^{\circ} \mathrm{C}$ and $10^{\circ} \mathrm{C}$.

A more recent ongoing study performed by Koopman et al. (2017) to characterize $V$. inaequalis isolates from various regions in South Africa, including EL and the $\mathrm{KB}$, using genotyping indicated that the populations from the EL region was genetically distinct from the others. It is possible that the isolate with the optimal range of $1^{\circ} \mathrm{C}$ to $10^{\circ} \mathrm{C}$ for pseudothecial production predominates in the $\mathrm{KB}$ population, but that the isolate that produces pseudothecia at temperatures between $10^{\circ} \mathrm{C}$ and $20^{\circ} \mathrm{C}$ predominates in the EL population (Louw 1951). If so, then it can be speculated that the PD for the EL-KB leaf sets, although slightly higher during both years, did not differ significantly from that of the EL-EL leaf sets because of the countervailing influence of the genotype of these isolates in each region (Koopman et al. 2017). Temperatures in the EL region have increased during recent years because of climate change, which has impacted apple production (Midgley and Lötze 2011). Furthermore, temperatures in $\mathrm{KB}$ are expected to become warmer than they have been previously (Midgley and Lötze 2011). This study indicated the high plasticity of the genomes of the fungal pathogen to adapt to climate change.

PD values for 2012 and 2013 ranged from 12.7 to 24.7 p/f. These parameters are similar to ranges reported previously ( -9 to $33 \mathrm{p} / \mathrm{f}$ Jeger et al. (1982); -13.6 to $20.4 \mathrm{p} / \mathrm{f}$ Jeger (1984); and -8 to $57 \mathrm{p} / \mathrm{f}$ Gadoury and MacHardy (1986)). Meszka et al. (2008) and Jeger et al. (1982) found significant differences between cultivars in

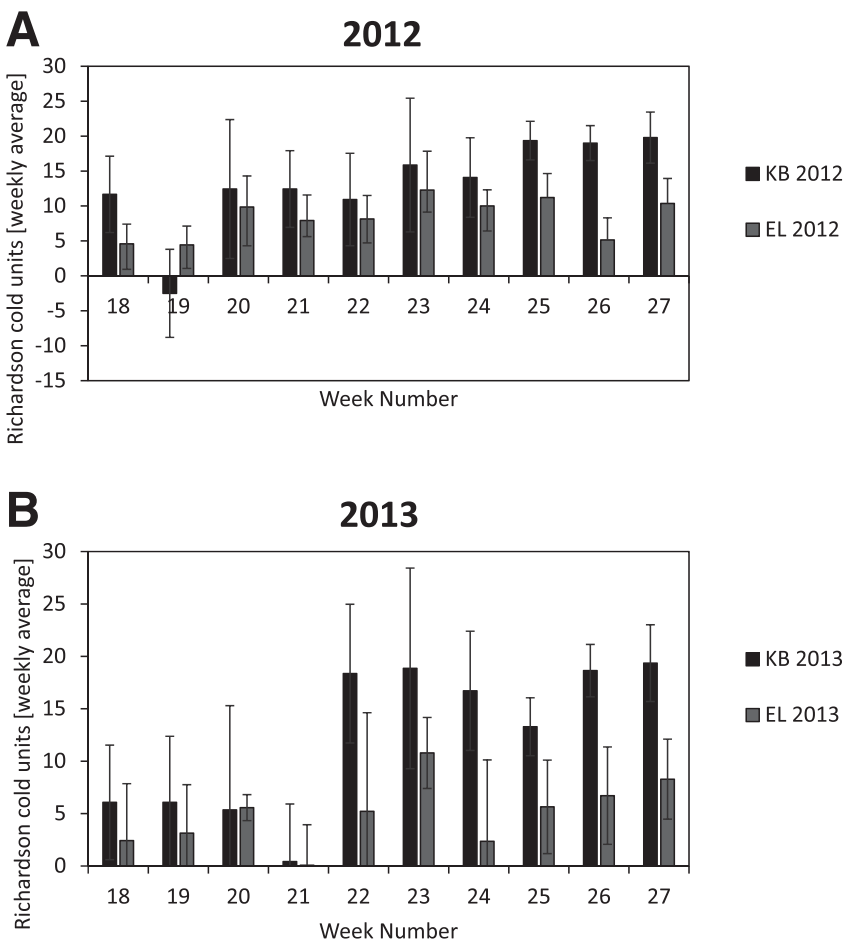

Fig. 4. Average weekly cold units in seasons A, 2012 and B, 2013 in the Elgin (EL) and Koue Bokkeveld (KB). Error bars indicate the standard deviation of daily averages. pseudothecial densities, whereas James and Sutton (1982a) and Cruz (1998) did not. Whether PD constants need to be calculated for various cultivars in the different climatic apple production regions in South Africa remains to be determined. However, information regarding PD in each region is important for accurately determining the PAD in fall and the associated scab infection risk in spring (Gadoury and MacHardy 1986). The delayed leaf-drop, which extends up to 2 months in EL, could have contributed to the observed differences between regions (von Diest et al. 2016).

In 2012 and 2013, significant weekly temperature differences between the region of origin and region of overwintering did not significantly influence the mean $\mathrm{AD}$ of leaf sets that originated in one region and overwintered in the other region. The $>2.3^{\circ} \mathrm{C}$ higher mean temperatures in EL in 2012 and 2013 had no effect on AD when the two overwintering treatments were compared.

The mean AD in 2012 and 2013 (range, 128.8 to $162.1 \mathrm{a} / \mathrm{p}$ ) was higher than the mean AD reported in the United States $(122 \mathrm{a} / \mathrm{p}$; SD $\pm 7.9 \mathrm{a} / \mathrm{p}$ ) (Gadoury and MacHardy 1986). Nevertheless, the effect of temperature on ascus development could be confirmed when mean temperatures during ascal formation periods and $\mathrm{AD}$ were plotted [Figure 8a in Gadoury and MacHardy (1986)]. This further indicated that the $\mathrm{AD}$ in this study followed the expected trend. The trend toward a higher number of ascospores in SA orchards compared with those in orchards in the United States suggested that factors other than temperatures and rainfall occurring in winter may have influenced the AD in leaf sets in 2012 and 2013. AD was only determined once [not weekly, as suggested by Gadoury and MacHardy (1982a)]. However, AD increases only until the first ascospores start to mature (Gadoury et al. 1984), and mature ascospores were found in asci counted in both years (average $51 \%$ of asci across all treatments contained mature asci in 2012). Disintegration of empty asci was not considered, but because so few asci had been discharged (average $0.5 \%$ of asci across all treatments had discharged their asci in 2012) and, therefore, disintegrated, AD results in 2012 and 2013 should still be sufficiently accurate to determine whether differences exist between treatments.

Both regions (KB and EL) had unusually low or no rainfall in week 31 in 2013. Because moisture can be a limiting factor in ascal formation (James and Sutton 1982a), this may explain why AD of KB-KB, EL-EL, and KB-EL treatments were lower in 2013 than in 2012. In 2012, the KB region experienced cooler weather conditions prior to the start of the experiment at leaf-drop (weeks 19 to 23), which may have influenced the physiology of the pathogen, whereas other orchard-specific factors such as soil type probably would not have influenced production of ascospores. Both orchards were equally susceptible to scab infection, with high incidence and severity observed (von Diest et al. 2016). Nevertheless, the use of a defoliant to shorten the leaf-drop period should be investigated using a future experimental setup.

The higher $\mathrm{AD}$ values in this study could support theories such as the South African population including a different strain, or multiple strains, not found in the northeastern United States. As mentioned, two previous studies have provided evidence for this hypothesis (Koopman et al. 2017; Louw 1951). Similar to the PD results, a minimum of two more seasons would be required to verify these results before an $\mathrm{AD}$ constant could be determined and used in practice.

The reason why PD, but not AD, differed between EL-EL and EL-KB treatments could be related to a fitness factor that has resulted from an adaptation of the EL population to warmer winter temperatures over a number of decades, which can be attributed to climate change (Midgley and Lötze 2011). One possible explanation is that, because PD did not differ significantly when leaves from EL were moved to $\mathrm{KB}$, the $V$. inaequalis population in EL has adapted to form consistently fewer pseudothecia at higher temperatures. It could be that, because the region is warmer and leaf-drop is delayed by up to 2 months compared with other apple-growing regions, the EL population has also adapted to form fewer pseudothecia during a shorter winter period. This would allow for fewer pseudothecia to mature faster in a shorter time period because competition for resources is lessened. The 
fungus could instead spend energy on ascal formation and maturation sooner, so that ascospore discharge is closer to bud-break. In the future, if the climate in the Western Cape continues to change as predicted (Midgley and Lötze 2011), then this shift may become more significant.

This is the first study to evaluate differences in PD and AD between regions with different winter climates. Therefore, the results will aid in determining the PD and $\mathrm{AD}$ constants for the $\mathrm{KB}$ and EL regions in the future. These studies should be repeated using multiple orchards in each region over at least two additional seasons. Furthermore, a simplified approach such as that suggested by Gadoury and MacHardy (1986) should be considered. This could be achieved, for example, by using the Vanderplank (1963) equation that describes the relationship between inoculum and disease development. This might aid growers who are trying to determine regional differences in apple scab inoculum and associated infection risks. Such information could be useful for developing a more accurate risk prediction system to determine which orchards carry the highest risk for scab in the following season. Inoculum levels in those orchards could be addressed first, and preventative spray applications in spring could be applied to those orchards first in spring.

\section{Acknowledgments}

We thank the South African pome fruit growers for participation in this study. We also thank ileaf.co.za for access to weather data, Prof. Martin Kidd for statistical analysis, and Prof. Douglas E. Rawlings for editing the manuscript.

\section{Literature Cited}

Anderson, J. L., Richardson, E. A., and Kesner, C. D. 1986. Validation of chill unit and flower bud phenology models for 'Montmorency'sour cherry. Acta Hortic. 184:71-78.

Blanquart, F., Kaltz, O., Nuismer, S. L., and Gandon, S. 2013. A practical guide to measuring local adaptation. Ecol. Lett. 16:1195-1205.

Brook, P. J. 1969. Effect of light, temperature, and moisture on release of ascospores by Venturia inaequalis (Cke.) Wint. N. Zeal. J. Agr. Res. 12:214-227.

Cook, N. C. 2010. Apple production under conditions of sub-optimal winter chilling in South Africa. Acta Hortic.: 199-204.

Cruz, M. 1998. The production of pseudothecia and asci of Venturia inaequalis in three apple cultivars. Proceedings of the 7th International Congress of Plant Pathology, Edinburgh. ICPP 98: 3.7.88.

Gadoury, D. M., and MacHardy, W. E. 1982a. Preparation and interpretation of squash mounts of pseudothecia of Venturia inaequalis. Phytopathology 72: 92-95.

Gadoury, D. M., and MacHardy, W. E. 1982b. Effects of temperature on the development of pseudothecia of Venturia inaequalis. Plant Dis. 66:464-468.

Gadoury, D. M., and MacHardy, W. E. 1986. Forecasting ascospore dose of Venturia inaequalis in commercial apple orchards. Phytopathology 76: 112-118.

Gadoury, D. M., MacHardy, W. E., and Hu, C. C. 1984. Effects of temperature during ascus formation and frequency of ascospore discharge on pseudothecial development of Venturia inaequalis. Plant Dis. 68:223-225.

Gadoury, D. M., Seem, R. C., MacHardy, W. E., Wilcox, W. F., Rosenberger, D. A., and Stensvand, A. 2004. A comparison of methods used to estimate the maturity and release of ascospores of Venturia inaequalis. Plant Dis. 88: 869-874.

Gadoury, D. M., Stensvand, A., and Seem, R. C. 1998. Influence of light, relative humidity, and maturity of populations on discharge of ascospores of Venturia inaequalis. Phytopathology 88:902-909.

Gladieux, P., Zhang, X., Afoufa-Bastien, D., Valdebenito Sanhueza, R., Sbaghi, M., and Le Cam, B. 2008. On the origin and spread of the scab disease of apple out of Central Asia. PLoS One 3:e1455.
Hao, Z., Hao, F., Singh, V. P., and Zhang, X. 2018. Changes in the severity of compound drought and hot extremes over global land areas. Environ. Res. Lett. 13:124022.

Holb, I., and Heijne, B. 2002. Comparative study of Dutch and Hungarian environmentally-friendly apple orchards on potential ascospore dose of apple scab. J. Agric. Sci. 12:31-36.

James, J. R., and Sutton, T. B. 1982a. Environmental factors influencing pseudothecial development and ascospore maturation of Venturia inaequalis. Phytopathology 72:1073-1080.

James, J. R., and Sutton, T. B. 1982b. A model for predicting ascospore maturation of Venturia inaequalis. Phytopathology 72:1081-1085.

Jeger, M. J. 1984. Overwintering of Venturia inaequalis in relation to lesion intensity on leaf surfaces, and leaf surface exposed. Trans. Br. Mycol. Soc. 83:495-500.

Jeger, M. J., Swait, A. A. J., and Butt, D. J. 1982. Overwintering of Venturia inaequalis, the causal agent of apple scab, on different cultivars. Ann. Appl. Biol. 100:91-98.

Koopman, T. A., Meitz-Hopkins, J. C., Bester-van der Merwe, A. E., Bester, C., Tobutt, K. R., and Lennox, C. L. 2017. Genetic diversity and gene flow of four South African Venturia inaequalis (apple scab) populations. Phytopathology 107:455-462.

Kremer, W., and Unterstenhöfer, G. 1967. Computation of results of crop protection experiments by the method of Townsend and Heuberger. Höfchenbriefe: Bayer Pflanzenschutznachrichten 20:625-628.

Kunz, A., and Blanke, M. M. 2011. Effects of global climate change on apple 'Golden Delicious' phenology - based on 50 years of meteorological and phenological data in Klein-Altendorf. IXth International Symposium on Orchard Systems. Acta Hortic.: 1121-1126.

Louw, A. J. 1948. Variation and environmental effects in artificial cultures of Venturia inaequalis (Cke.) Wint, the cause of apple scab. Sci. Bull. Dep. Agric. S. Afr. 248:1-20

Louw, A. J. 1951. Studies on the influence of environmental factors on the overwintering and epiphytology of apple scab [Venturia inaequalis (Cke.) Wint.] in the winter-rainfall area of the Cape Province. Sci. Bull. Dep. Agric. S. Afr. 310:1-48

MacHardy, W. E., Gadoury, D. M., and Gessler, C. 2001. Parasitic and biological fitness of Venturia inaequalis: relationship to disease management strategies. Plant Dis. 85:1036-1051.

Meitz-Hopkins, J. C., von Diest, S. G., Koopman, T. A., Bahramisharif, A., and Lennox, C. L. 2014. A method to monitor airborne Venturia inaequalis ascospores using volumetric spore traps and quantitative PCR. Eur. J. Plant Pathol. 140:527-541.

Meszka, B., Masny, S., and Bielenin, A. 2008. Study on Venturia inaequalis pseudothecial development, ascospore discharge and prediction of apple scab. Zemdirbyste-Agriculture 95:116-122.

Midgley, S. J. E., and Lötze, E. 2011. Climate change in the Western Cape of South Africa: Trends, projections and implications for chill unit accumulation. Acta Hortic.: 1127-1134.

Romanovskaja, D., and Bakšiene, E. 2009. Influence of climate warming on beginning of flowering of apple tree (Malus domestica Borkh.) in Lithuania. Agron. Res. (Tartu) 7:87-96.

Shobe, W. R., and Lersten, N. R. 1967. A technique for clearing and staining gymnosperm leaves. Bot. Gaz. 128:150-152.

Sutton, D. K., MacHardy, W. E., and Lord, W. G. 2000. Effects of shredding or treating apple leaf litter with urea on ascospore dose of Venturia inaequalis and disease buildup. Plant Dis. 84:1319-1326.

Szkolnik, M. 1969. Maturation and discharge of ascospores of Venturia inaequalis. Plant Dis. Rep. 53:534-537.

Vanderplank, J. E. 1963. Plant Diseases: Epidemics and Control. Academic Press, New York.

von Diest, S. G., Meitz-Hopkins, J. C., MacHardy, W. E., and Lennox, C. L. 2016 The effect of leaf shredding on apple scab in South African orchards. Plant Dis. 100:2094-2098

Wilson, E. E. 1928. Studies on the ascigerous stage of Venturia inaequalis (Cke.) Wint. in relation to certain factors of the environment. Phytopathology 18: 375-418. 